\title{
TOWARDS ENHANCING VALUES OF ACCOUNTABILITY AND TRANSPARENCY FOR ACTIVATING PARTICIPATORY PLANNING
}

\section{Noha Ahmed Nabil}

Associate Professor at Architecture Department, Helwan University, Faculty of Engineering, Cairo, Egypt

(Received June 30, 2011 Accepted August 17, 2011)

Urban management in Egypt faces several challenges in view of globalization and agreements of trade and sustainability concepts so it was necessary for urban management to keep pace of era requirements and challenges and fulfils its needs.

Several concepts appeared that are related to progress in urban management such as partnership, time management, transparency, accountability and other concepts that began to intervene space of application in communities and projects. Concept of Participatory Planning is one from these concepts which became used concepts in our several national projects.

Transparency and accountability are considered two main ingredients of urban management that forms a preceding condition of sustainability development achievement conditions. They are two correlated concepts that enhance each other, accountability can't be found in absence of transparency, if there is no accountability, transparency won't have any value.

So this research paper aims at finding methodological steps for enhancing accountability and transparency in urban planning projects for activating Participatory Planning.

Research plan depends on 4 main axes (aspects):

The first axis: identifying concepts of transparency and accountability and the requirements and indicators of applying them.

The second axis: identifying concept of Participatory Planning and the requirements of applying it to find role of transparency and accountability in activating Participatory Planning.

The third axis: conducting a questionnaire for measuring indicators of transparency and accountability in a number of Participatory Planning projects in slum.

The fourth axis: finding methodological steps for enhancing values of transparency and accountability of Participatory Planning projects of slum.

All development partners should follow steps that enhance values of transparency and accountability, setting defined plans to fulfill these values in participatory planning projects in slum, activating as well these projects' performance and role to acquire them credibility of population. 


\section{TRANSPARENCY AND ACCOUNTABILITY}

Transparency and accountability are essential to stakeholder since it creates an environment of trust and openness, which results in collaboration and partnerships in addressing urban challenges.

Transparency became a main component in formal political address, civil community address and public view as considered one of globalization terms recently.

\subsection{Transparency Concept}

Transparency is a key tool used to operational lines of accountability. It can be defined as the steady and reliable availability of relevant information to stakeholders.

Transparency mechanisms are procedural and structural aspects of an organization that make this information available and accessible by the stakeholders ${ }^{1}$.

Transparency is based also on generalizing information related to citizens' rights and services they receive and means of getting these rights such as process of choosing those in charge of local authority and monitoring and replacing them and government ability on managing its resources effectively and executing intact policies and respecting citizens and government to country's policies ${ }^{2}$.

Transparency definition from developmental perspective is population ability on getting all information related to developmental project or is defined as publicity in local councils' performance to all their projects.

In the light of the above definitions the research paper concludes that transparency concept stipulates clarity of systems and procedures in decision making centers, authorities and local councils and relation between them and population benefiting from its services and publicity of procedures, aims and objectives at any developmental project and providing information periodically without request or during request from any person and also information about those in charge of project and their roles and responsibilities.

\section{1-1-1 Transparency Indicators}

There are several indicators that should be provided to achieve transparency at any developmental projects; these indicators depend on availability of:

- Providing information in form of clear booklets about project objectives and program and its availability to population at any time.

- Providing information for population about main system and organizational chart of project and those in charge of it and its budget ${ }^{3}$.

- Working on engaging population benefiting from developmental project in forming developmental plans and executing them.

- Local councils' coordinate their activities and programs with local partners, and partners from benefiting population should be there. ${ }^{4}$

- Spreading periodical reports about the project, its objectives and financed authorities.

- Public policy of publication and disclosure of information for benefiting population through providing these information continuously and existence of public policy that identifies principles of getting it. 


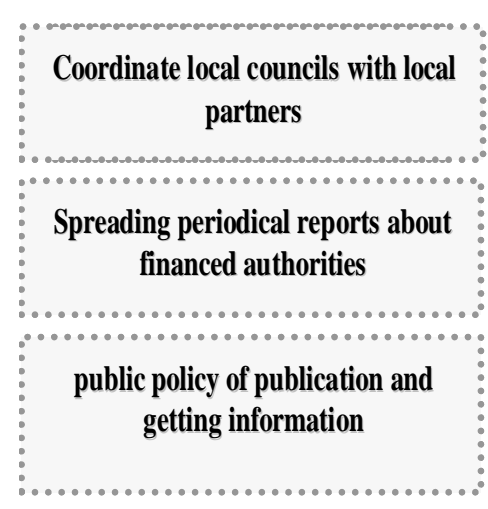

Shape (1) transparency indicators
Providing information about objectives of project and its program

Transparency

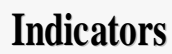

"Source. Researcher. Preparing"

\section{1-1-2 Transparency Dimensions}

Previous indicators are related to transparency dimensions, these dimensions are represented in ${ }^{5}$ :

- Content: it includes all data that can be published and put in front of aimed category.

- Publication range and place: where data and information concerning specific project can be published.

- Aimed population category: are they members of local councils or benefiting population or population generally.

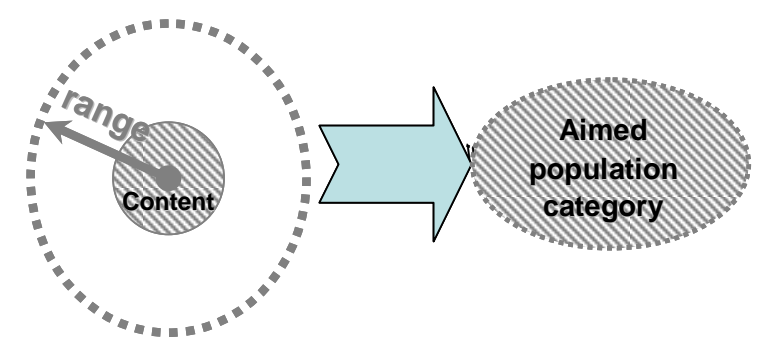

Shape (2) Transparency dimensions "Source. Researcher Preparing"

\section{1-1-3 Transparency Conditions}

There are several conditions that should be available when achieving transparency.

1- Transparency should be done at appropriate time as late transparency is usually valueless and is announced sometimes to fulfill the form ${ }^{6}$.

2- Transparency should be available for all parties at the same time.

3- Transparency should be clear for all announcers; there is no value of ambiguous transparency.

4- Transparency should be followed by accountability, transparency isn't an end but a mean to display mistakes and accounting its committers in a frame of legal means organized for that. 


\section{1-2 Accountability Concepts}

Accountability in its basic sense implies rendering of accounts and by extension, indicates answerability to an external agency or group and, further, implies ensuring propriety, legality and safeguarding public interest in satisfaction of the expectations of the external agency or group7.

Definition of accountability as "that process that requires us to disclose fully and truthfully our performance to those who are entitled to know." this definition to see that it could apply in all situations, not just limited to government. To understand the full implications of this definition it is best to deconstruct it and look at each of the obligations separately.

First, it states "requires us to disclose." Disclosure is not a matter of choice but a matter of obligation. Disclosure also must mean to publish in some form either by verbal statement or by written document. Just acting in a responsible manner is not enough.

Preferably the disclosure of actions taken must be published in a form able to be scrutinized by others.

Second, it says "fully and truthfully," meaning partial disclosure is not enough. Partial disclosure may lead those who are entitled to make judgments on performance to arrive at the wrong conclusion because they were not fully informed. Truthfully means that disclosure must be based on fact, not conjecture, supposition, or impression. That also means stated in disclosure reports must be backed up by evidence and verifiable in some way.

Third, "performance" in this context means the results of actions taken or what was achieved must also be described. Simply disclosing actions taken is not indicative at all of actual progress achieved towards an actual outcome.

Finally, "to those who are entitled to know" means those who employ you, those who place their trust in you, those on whose behalf you take actions that may affect their lives, so it is not necessarily everyone that you need to disclose to but only those to whom you owe a duty as you execute your actions. ${ }^{8}$

\section{1-2-1 Accountability Indicators}

There are several indicators that should be available for achieving accountability at any developmental projects; these indicators depend on availability of 9

- There is a responsible structure about achieving accountability in different administrative levels.

- There are periodical follow up reports that include technical, financial and administrative aspects.

- Regularity of participant categories meeting in the project.

- Availability of several mechanisms for achieving communication between participant categories between each other.

- Availability of several mechanisms for achieving communication between participant categories and actual beneficiaries.

- There are mechanisms for achieving following up and monitoring through periodical follows up reports, field investigation and periodical meetings.

- Evaluating programs projects and plans periodically. 


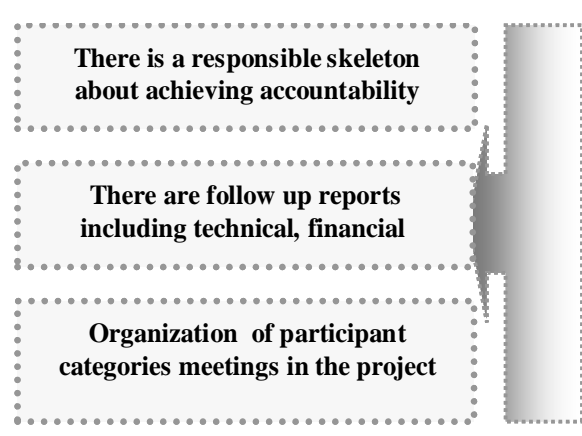

Shape (3) Accountability indicators

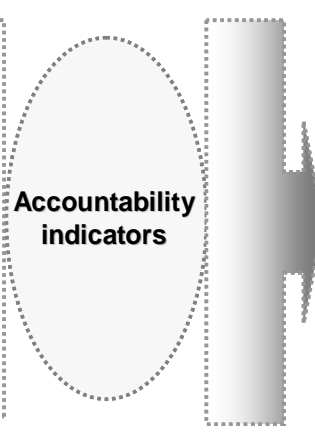

Availability of mechanisms for achieving communication between participant categories and beneficiaries

Existence of mechanisms for achieving follow up and supervision

Evaluating programs, projects and plans periodically

\section{1-2-2 Types of Accountability}

There are two Types of accountability, they are represented in:

- Vertical accountability: it indicates ability of electors on questioning their representatives across reelecting them or not reelecting them.

- Horizontal accountability: it indicates submission of each authority or responsible to monitoring and accountability by other authority as there is no one out of accountability.

Through these concepts research defines accountability as : To enable citizens and non-governmental organizations to monitor and account public employees and those in charge generally through appropriate channels and tools without leading to break downing or misusing work without valid reason.

The accountability of local authorities to their citizens must be a paramount concern; there is no place for corruption in cities. Transparency and accountability are essential in allowing stakeholders to have insight into local government operations and to assess which sectors of society are benefiting from decisions and actions. Universal access to, and the free flow of, information is fundamental to transparent and accountable governance. Laws and public policies should be applied in a transparent and predictable manner. Public officials should adhere to high standards of professional and personal integrity ${ }^{10}$.

\section{1-2-3 Conditions of Achieving Accountability}

There are several conditions that make accountability effective that is identified in:

First: there should be an integrated program of the project indicating its objectives, strategies and benefiting categories and stages, it also includes project budgets, expenses and revenues.

Second: providing an integrated database for the project as accountability is done according to provided data ${ }^{11}$.

Third: There is an organizational chart in which characteristic all lower authorities submission to higher authorities accountability and follow up, it also provides systems that identify mechanisms and forms of relation between these authorities, this means providing a system that identifies nature and form of accountability as considered legal frame including rules that identify rights, duties, and responsibilities of authorities and members. 


\section{Participatory Planning:}

Participatory planning refers to the process by which the hitherto passive recipients of development become actors and governmental departments their agents both acting in coordination to identify felt needs and prioritize them as per the resources that can be mobilized through a social and political acceptable form of negotiation through the intermediation and supervision of elected local governments. In order to satisfy the cannons of development planning there has to be infusion of professionalism preferably in a spirit of voluntarism so that people's ideas and expert opinion can blend seamlessly. And to ensure realism and definiteness, planning has to be against a budget revealed in advance fairly allocated and eked out by local resource mobilization. In such a scenario participatory planning becomes participatory budgeting.

In order to ensure that national and regional objectives of development get harmonized with local level needs and aspirations a framework is needed for participatory planning without being restrictive. Finally to make the whole exercise, legally and administratively valid, the existing rules and regulations have to be suitably restructured to enable participation.

\section{2-1 Advantages Participatory Planning Why Participatory Planning?}

Participatory Planning, as an entry point to decentralization, has several advantages. They include:

i) Planning is relevant to all local governments, developed and under-developed, urban and rural, big and small.

ii) Participatory planning facilitates the involvement of different sections of society each having different development interests and expectations; it affords opportunities for activists, volunteers and professionals to contribute to reconciling the different interests into a development agenda, in partnership with elected representatives and government officials.

iii) Participatory local level planning throws up local solutions to difficult development problems unfettered by technological, institutional or ideological fixations.

iv) It motivates people to back up their participation with contribution in cash, kind or labor, to stretch out public resources to match the requirements as per local priorities.

v) Participatory planning implies local data collection and analysis facilitated by experts - this is a good base for reflection and developmental action, leading ultimately to empowerment.

vi) It facilitates accountability through enhanced information flow as well as awareness of deeper developmental issues.

vii) Participatory planning generates the desire for developmental learning, affording entry to concepts like gender, social justice, environmental sustainability, mainstreaming the challenged and so on.

Participatory planning is only a beginning. If properly managed. ${ }^{12}$

International bank identified four methods of participatory planning to express partnership between parties which are:

- Partnership in information 
- Discussion about partnership subject

- Decisions making

- Right of participating parties in suggestion or modification and displaying on participating parties to take appropriate decision after agreement.

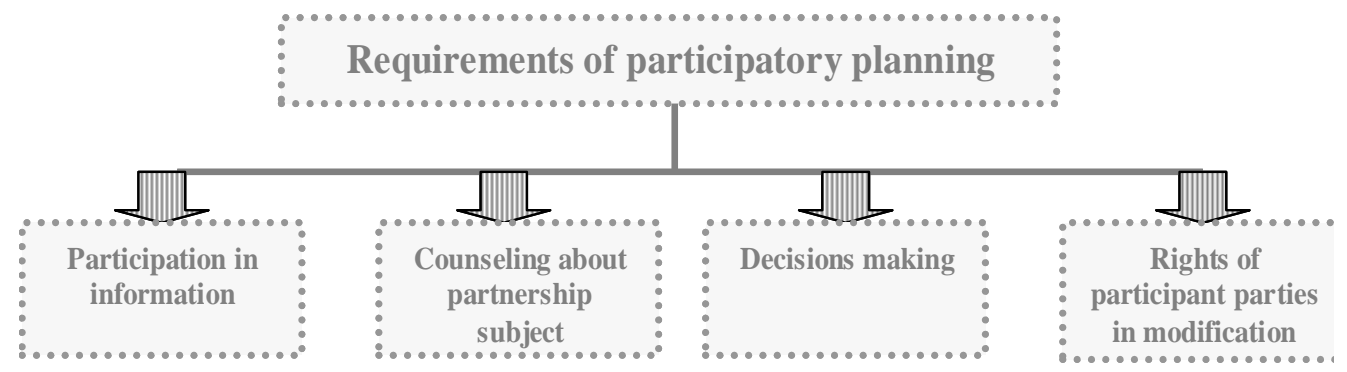

Shape (4) Requirements of participatory planning "Source. Researcher Preparing"

Experts agreed that partners should be divided in process of participatory planning and their roles and responsibilities should be identified

Partners can be divided into two groups as what follow:

\section{2-2 Partners:}

\section{Firstly: "Governmental partners "governmental organizations:}

- Central Government (C.G): It is the main controller in development process as it is controller in the living environment on the national level, and also it may be ministries and specialized central organizations and take its strength from its monopoly for the roles of making-a decision and choosing the development forms and achieving its plans and distributing its revenues ${ }^{13}$.

The central government is characterized by it control the Locality Government politically and administratively, also it distributes the main resources and finances the organizational structures, and it is the strongest direction contributing financially, also it works to co-ordinates among the Locality Government and the special sector.

- Locality Government (L.G): It means the government of the elected city or appointed on all its levels starting from governorates, passing at the local units and the local common councils. And this governmental level takes the daily responsibility of growth and the urban development.

The Locality Government is characterized by the following:

- Financing and maintaining the basic services, this may be done directly or through co-operation with the private sector and non-governmental organizational.

- Most of the Locality Government members of a pointed man, who aren't chosen on a base of election. ${ }^{14}$ 
- Elected local popular councils (L.P.C): which haven't got the control right on the government performance and the right of revising the plans of sustainable development and takes its strength through its representation for the citizens?

\section{Secondly: Non-governmental partners "non-governmental organizations "NGOs:}

We can classify it into two main groups, they are:

\section{Special organizations for the profit (S.O.P):}

These organizations contain both of groups, companies, and small and private projects which have got economical interests inter the regions which exist inter the boundary of development projects, and these organizations are different as to size and legality, that it is about from global company to small project or workshop ${ }^{15}$.

These projects aim at contributing in the development processes and profits either through developing the region where is the project or by avoiding some complex issues such as taxes and workers' rights.

\section{Special organizations not for profit:}

- Non-governmental organizations (NGOs): It contains unions and associations where were founded to guarantee achievement of aims without looking at the material earnings, it consists of groups of professional individuals help people of special region. Their role is represented in increasing funds which are necessary for the sustainable development projects. ${ }^{16}$

- Social organizations (S.O): It contains all the formal and informal organizations where were founded on a base of group of common population work together to achieve the general interests ${ }^{17}$.

- Benefiting populations (B.P): Region's residents play main role in the development projects because they are considered main partner, and they are classified according to the society levels- where is developed- and according to their role distribution ${ }^{18}$.

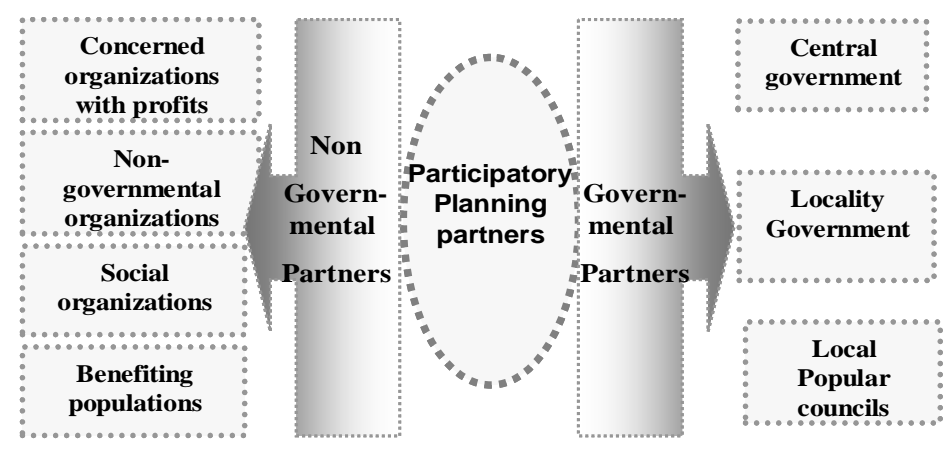

Shape (5) Participatory Planning partners "Source. Researcher Preparing"

Through what was previously mentioned we conclude that there is a correlative relation between transparency, accountability, governmental partners and non governmental partners, their roles are represented in the following table: 
Table (1) measuring indicators of proposed transparency and accountability according to development partners in participatory planning projects in random areas and their roles in achieving transparency and accountability indicators.

\begin{tabular}{|c|c|c|c|c|c|c|c|}
\hline \multirow{2}{*}{$\begin{array}{c}\text { Indicators of transparency } \\
\text { and accountability }\end{array}$} & \multicolumn{7}{|c|}{ Participatory Planning Partners } \\
\hline & C.G & L.G & L.P.C & S.O.P & NGO & S.O & B.P \\
\hline $\begin{array}{l}\text { Providing information about } \\
\text { project objectives \& program. }\end{array}$ & & & & & & & \\
\hline $\begin{array}{l}\text { Announcement of } \\
\text { organizational chart of project } \\
\text { and budget. }\end{array}$ & & & & & & & \\
\hline $\begin{array}{l}\text { Population participation in } \\
\text { forming plans and decision } \\
\text { making. }\end{array}$ & & & & & & & \\
\hline $\begin{array}{l}\text { Local council's coordination } \\
\text { with local partners. }\end{array}$ & & & & & & & \\
\hline $\begin{array}{l}\text { Publishing periodical reports } \\
\text { about financed authorities and } \\
\text { their roles. }\end{array}$ & & & & & & & \\
\hline $\begin{array}{l}\text { Public policy of publication } \\
\text { and getting information. }\end{array}$ & & & & & & & \\
\hline $\begin{array}{l}\text { A skeleton responsible for } \\
\text { accountability achievement. }\end{array}$ & & & & & & & \\
\hline $\begin{array}{l}\text { Consent reports include } \\
\text { technical, financial and } \\
\text { administrative aspects. }\end{array}$ & & & & & & & \\
\hline $\begin{array}{l}\text { Regularity of participant } \\
\text { categories meetings in the } \\
\text { project. }\end{array}$ & & & & & & & \\
\hline $\begin{array}{l}\text { Mechanisms availability for } \\
\text { achieving connection between } \\
\text { participant categories \& } \\
\text { beneficiaries. }\end{array}$ & & & & & & & \\
\hline $\begin{array}{l}\text { Mechanisms for achieving } \\
\text { follow up and monitoring in } \\
\text { the project }\end{array}$ & & & & & & & \\
\hline $\begin{array}{l}\text { Evaluating programs projects } \\
\text { \& plans periodically. }\end{array}$ & & & & & & & \\
\hline
\end{tabular}




\section{Field Study}

Field study aims at measuring indicators of transparency and accountability in participatory planning projects in slum to find a methodology for enhancing values of transparency and accountability which works on activating it according to participatory planning.

The study is applied on projects in slum that were chosen according to study fields:

Projects of developing slum were chosen in three different areas that belong to a pattern of slum patterns, they are combining between several shared merits that are represented in:

- The three projects have number of governmental and non-governmental partners.

- The three projects depended on principle of participatory planning.

- The first stages completed in all projects to measure transparency and accountability indicators during project or after completing it.

- The three projects have a main objective which is enhancing population living level.

- Benefiting population has a great role in achieving projects' main and sub objective.

\section{The Three Projects Differ Concerning:}

Difference between the three projects based on the different location of the Greater Cairo and the number of non-governmental partners to the project participants.

- A project of developing Ezaba Al-Walda in Helwan as one of projects that a great number of non-governmental partners participated in.

- A project of developing Ezaba Bekheet in Monshait Naser: as one of slum in borders of Cairo.

- A project of developing Bolak El-Dakror as one of slum in Center of Cairo.

\section{The First Project: Project of Participatory Planning in Ezaba Al- Walda in Helwan.}

Ezaba Al-Walda area lies in south of Cairo region beside Helwan university, a project for developing area was done, the main objective from this project is represented in improving living standard in Ezaba Al-Walda in Helwan and is achieved through improving social, economical, health and cultural level of area population and enhancing main structure level in the area as including improving environmental state, several projects were put to achieve these objectives such as establishing health center, roads paving, walkers pavements, building and developing schools and Azhar institute, codifying occupancy, establishing police station, developing market and central, several authorities participated in financing and executing this project, that are represented in:

Governmental partners: central government; Helwan governorate and Ministry of environment.

Non-governmental partners: non-governmental partners are divided into benefiting population, authorities supporting the project concerning financing and participation, they are represented in: 
Table (2) clarifies non governmental partners, their roles and responsibilities in participatory planning project in Ezaba Al-Walda in Helwan

\section{Non governmental Partners}

1 Project of urban development by participation subordinate to German agency of technical cooperation(GTZ)

2 Institute of cultural affairs

3 Future association

4 National council of woman and association of woman rise and development

5

Al-Ahly Bank

6 Fareed Khamees institution

7 Association of "Our sons are our future"

Evangelical Christian authority
Their roles and responsibilities in the project

A technical and financial support for all projects

Building abilities and national associations working in the area, and members of different committees, and giving loans for woman and youth

Making training programs for education executives in Ezaba Al-Walda

Extracting national number cards of women, and opening culturing classes for women and females in the area

Supporting medical convoys and medical centers

Social aids and supporting medical convoys

Visual correction and supporting technical activities and supporting libraries - building teachers abilities

Loans for small projects - productive activities

\section{The Second Project: a Project of Participatory Planning in Ezaba Bekheet in Monshait Naser.}

Monshait Naser lies in region of Cairo in Cairo governorate east of Autostrad road and area of Al-Fatemia Cairo and near from middle of Cairo, the public authority of constructional planning in 1999 prepared plans of Naser construction district including area of Ezaba Bekheet, as detailed plans of extension area was prepared by 7800 residential unit in addition to social and public services in order that development process continues in Ezaba Bekheet, organization lines are put, a fewest possible No. of buildings are eliminated and population are re-alleviated, water and sewage networks are improved in the area. Several authorities participated in financing and executing project.

Governmental Partners: public authority of constructional planning, Cairo governorate and Naser construction district.

Non-Governmental Partners: benefiting population and some authorities which are represented in: 
Table (3) clarifies non-governmental partners, their roles and responsibilities in participatory planning project in Ezaba Bekheet in Monshait Naser

\begin{tabular}{|c|c|c|}
\hline & Non-governmental partners & $\begin{array}{c}\text { Their roles and responsibilities in the } \\
\text { project }\end{array}$ \\
\hline 1 & $\begin{array}{l}\text { Project of urban development by } \\
\text { participation subordinate to } \\
\text { German agency of technical } \\
\text { cooperation and construction bank }\end{array}$ & $\begin{array}{l}\text { Technical and financial Supporting for all } \\
\text { projects }\end{array}$ \\
\hline 2 & Abu Dhabi fund & $\begin{array}{l}\text { Completing extension area and improving } \\
\text { water, electricity and sewage networks and } \\
\text { paving streets and service constructions }\end{array}$ \\
\hline
\end{tabular}

\section{The Third Project: Project of Urban Development by National Participation in Bolak El-Dakror Area.}

Bolak El-Dakror district is considered from great districts in Giza governorate, Oseem city is marked off the north, Faisal street is marked off south, rail way of upper Egypt is marked off east and road of Kafr Tahrmus is marked off west, Ministry of planning put a plan of urban development in the district by cooperation with Giza governorate and German agency of technical cooperation, the first stage of German Egyptian cooperation was planned through project agreement done in 23 December 98, integrated period of the project is 8 years along three stages, the project aims at improving living conditions, providing and improving services in random areas. This objective is achieved through applying means that coincide with population needs and priorities planned and executed in a form of joint projects with Bolak El-Dakror district and population, project activities in first stage concentrate in field of improving environmental conditions including cleanness campaigns through competitions and environmental awareness campaigns by cooperation with students of schools, training and educational workshops of volunteer environment pioneers and providing equipments of cleanness and completing extension network with drinking water to areas deprived from it and completing connecting sewage networks, the project included awareness campaigns about current credit programs and helping owners of small projects in getting credit and training on business administration in field of supporting youth.

Developing some markets was completed such as Zaneen market and developing several schools in the district, theses projects were done by cooperation with several authorities that are represented in:

Governmental Partners: central government and ministry of planning, Giza governorate and Bolak El-Dakror district.

Non-Governmental Partners: they are represented in benefiting population besides: 
Table (4) clarifies non-governmental partners, their roles and responsibilities in urban development project by national participation in Bolak El-Dakror.

\begin{tabular}{|l|l|l|}
\hline \multicolumn{2}{|l|}{ Non-governmental partners } & $\begin{array}{l}\text { Their roles and responsibilities in } \\
\text { the project }\end{array}$ \\
\hline 1 & \begin{tabular}{l|l|l|} 
Project of urban development by \\
cooperation subordinate to German \\
agency of technical cooperation \\
(GTZ)
\end{tabular} & $\begin{array}{l}\text { A technical and financial support for } \\
\text { all projects }\end{array}$ \\
\hline
\end{tabular}

\section{3-1 Questionnaire Form}

Questionnaire was conducted to measure transparency and accountability indicators in participatory planning projects in slum, by analyzing joint elements in the three projects; they can be divided into several participation categories in transparency and accountability measure indicators which are:

1. The first category: governmental partners and extent of their information about transparency and accountability that should be provided in participatory planning projects in slum.

2. The second category: non governmental and social organizations and extent of their achievement to transparency and accountability indicators in their organizations and in their dealing with governmental partners and benefiting population.

3. The third category: benefiting population from participatory planning projects in slum to measure transparency and accountability indicators towards governmental partners, non-governmental organizations and social organizations.

Questionnaire appendix (1) was directed to the third category that is represented in benefiting population to measure extent of their information about transparency and accountability indicators in the three participatory planning projects, first according to governmental partners and second to non-governmental organizations then questionnaire was conducted to identify the most important procedures that enhance transparency and accountability values in participatory planning projects according to benefiting population.

\section{3-2 Discussing and Interpreting Results}

Questionnaire for measuring transparency indicators was conducted for population towards role of governmental partners, questionnaire results appeared as what follow: 


\section{The Results of the First Project}

Table No (5) results of measuring indicators of transparency and accountability of development partners in project of participatory planning in Ezaba Al-Walda in

\section{Helwan.}

\begin{tabular}{|l|c|c|c|c|c|}
\hline \multirow{2}{*}{$\begin{array}{c}\text { Indicators of transparency and } \\
\text { accountability }\end{array}$} & \multicolumn{4}{|c|}{ Partners of Participatory Planning } \\
\cline { 3 - 6 } & C.G & L.G & P.C & NGOs & S.O \\
\hline $\begin{array}{l}\text { Providing information about project } \\
\text { objectives and its program. }\end{array}$ & $\mathbf{1 5 \%}$ & & & & \\
\hline $\begin{array}{l}\text { Announcement of organizational chart of } \\
\text { project and its budget. }\end{array}$ & $\mathbf{3 0 \%}$ & $\mathbf{3 5 \%}$ & $\mathbf{3 5 \%}$ & & \\
\hline $\begin{array}{l}\text { Population participation in forming plans } \\
\text { and decision making. }\end{array}$ & $\mathbf{3 5 \%}$ & $\mathbf{4 5 \%}$ & $\mathbf{6 5 \%}$ & $\mathbf{6 0 \%}$ & \\
\hline $\begin{array}{l}\text { Local councils coordination with local } \\
\text { partners }\end{array}$ & & $\mathbf{6 0 \%}$ & $\mathbf{6 0 \%}$ & $\mathbf{6 5 \%}$ & \\
\hline $\begin{array}{l}\text { Publishing periodical reports about } \\
\text { financed authorities and their roles. }\end{array}$ & & $\mathbf{2 5 \%}$ & $\mathbf{2 5 \%}$ & & \\
\hline $\begin{array}{l}\text { Public policy of publication and getting } \\
\text { information. }\end{array}$ & $\mathbf{3 5 \%}$ & $\mathbf{3 5 \%}$ & $\mathbf{3 5 \%}$ & $\mathbf{6 5 \%}$ & $\mathbf{6 5 \%}$ \\
\hline $\begin{array}{l}\text { A skeleton responsible for accountability } \\
\text { achievement. }\end{array}$ & $\mathbf{3 0 \%}$ & $\mathbf{3 0 \%}$ & $\mathbf{3 0 \%}$ & & \\
\hline $\begin{array}{l}\text { Consent reports include technical, } \\
\text { financial and administrative aspects. }\end{array}$ & $\mathbf{1 5 \%}$ & $\mathbf{1 5 \%}$ & $\mathbf{1 5 \%}$ & $\mathbf{1 0 \%}$ & $\mathbf{1 0 \%}$ \\
\hline $\begin{array}{l}\text { Regularity of participant categories } \\
\text { meetings in the project }\end{array}$ & $\mathbf{3 5 \%}$ & $\mathbf{3 5 \%}$ & $\mathbf{3 0 \%}$ & $\mathbf{7 0 \%}$ & $\mathbf{6 0 \%}$ \\
\hline $\begin{array}{l}\text { Mechanisms availability for achieving } \\
\text { connection between participant categories } \\
\text { and beneficiaries. }\end{array}$ & $\mathbf{2 0 \%}$ & $\mathbf{2 5 \%}$ & $\mathbf{2 5 \%}$ & $\mathbf{6 0 \%}$ & $\mathbf{6 0 \%}$ \\
\hline $\begin{array}{l}\text { Mechanisms for achieving follow up and } \\
\text { monitoring in the project. }\end{array}$ & $\mathbf{2 0 \%}$ & $\mathbf{2 0 \%}$ & $\mathbf{2 0 \%}$ & & \\
\hline $\begin{array}{l}\text { Evaluating programs, projects and plans } \\
\text { periodically. }\end{array}$ & $\mathbf{1 5 \%}$ & $\mathbf{1 5 \%}$ & & & \\
\hline
\end{tabular}




\section{The Results of the Second Project}

Table No (6) results of measuring indicators of transparency and accountability of development partners in project of participatory planning in Ezaba Bekheet in Monshait Naser.

\begin{tabular}{|l|c|c|c|c|c|}
\hline \multicolumn{2}{|c|}{$\begin{array}{c}\text { Indicators of transparency and } \\
\text { accountability }\end{array}$} & \multicolumn{3}{|c|}{ Partners of Participatory Planning } \\
\cline { 2 - 6 } & C.G & L.G & P.C & NGOs & S.O \\
\hline $\begin{array}{l}\text { Providing information about project } \\
\text { objectives and its program. }\end{array}$ & $\mathbf{5 \%}$ & & & & \\
\hline $\begin{array}{l}\text { Announcement of organizational chart of } \\
\text { project and its budget. }\end{array}$ & $\mathbf{2 0 \%}$ & $\mathbf{2 5 \%}$ & $\mathbf{2 5 \%}$ & & \\
\hline $\begin{array}{l}\text { Population participation in forming plans } \\
\text { and decision making. }\end{array}$ & $\mathbf{3 0 \%}$ & $\mathbf{4 5 \%}$ & $\mathbf{6 0 \%}$ & $\mathbf{6 0 \%}$ & \\
\hline $\begin{array}{l}\text { Local councils coordination with local } \\
\text { partners }\end{array}$ & & $\mathbf{4 0 \%}$ & $\mathbf{4 0 \%}$ & $\mathbf{4 0 \%}$ & \\
\hline $\begin{array}{l}\text { Publishing periodical reports about } \\
\text { financed authorities and their roles. }\end{array}$ & & $\mathbf{1 0 \%}$ & $\mathbf{1 0 \%}$ & & \\
\hline $\begin{array}{l}\text { Public policy of publication and getting } \\
\text { information. }\end{array}$ & $\mathbf{3 5 \%}$ & $\mathbf{3 5 \%}$ & $\mathbf{3 5 \%}$ & $\mathbf{5 0 \%}$ & $\mathbf{5 0 \%}$ \\
\hline $\begin{array}{l}\text { A skeleton responsible for accountability } \\
\text { achievement. }\end{array}$ & $\mathbf{3 0 \%}$ & $\mathbf{3 0 \%}$ & $\mathbf{3 0 \%}$ & & \\
\hline $\begin{array}{l}\text { Consent reports include technical, } \\
\text { financial and administrative aspects. }\end{array}$ & $\mathbf{5 \%}$ & $\mathbf{5 \%}$ & $\mathbf{5 \%}$ & $\mathbf{1 0 \%}$ & $\mathbf{1 0 \%}$ \\
\hline $\begin{array}{l}\text { Regularity of participant categories } \\
\text { meetings in the project }\end{array}$ & $\mathbf{3 0 \%}$ & $\mathbf{3 0 \%}$ & $\mathbf{3 0 \%}$ & $\mathbf{5 0 \%}$ & $\mathbf{4 0 \%}$ \\
\hline $\begin{array}{l}\text { Mechanisms availability for achieving } \\
\text { connection between participant categories } \\
\text { and beneficiaries. }\end{array}$ & $\mathbf{1 5 \%}$ & $\mathbf{2 0 \%}$ & $\mathbf{2 5 \%}$ & $\mathbf{4 0 \%}$ & $\mathbf{4 0 \%}$ \\
\hline $\begin{array}{l}\text { Mechanisms for achieving follow up and } \\
\text { monitoring in the project. }\end{array}$ & $\mathbf{1 0 \%}$ & $\mathbf{1 0 \%}$ & $\mathbf{1 0 \%}$ & & \\
\hline $\begin{array}{l}\text { Evaluating programs, projects and plans } \\
\text { periodically. }\end{array}$ & $\mathbf{5 \%}$ & $\mathbf{5 \%}$ & & & \\
\hline
\end{tabular}




\section{The Results of the Third Project}

Table No (7) results of measuring indicators of transparency and accountability of development partners in project of urban development by national participation in Bolak El-Dakror area.

\begin{tabular}{|l|c|c|c|c|c|}
\hline Indicators of transparency and accountability & \multicolumn{3}{|c|}{ Partners of Participatory Planning } \\
\cline { 2 - 6 } & C.G & L.G & P.C & NGOs & S.O \\
\hline $\begin{array}{l}\text { Providing information about project objectives } \\
\text { and its program. }\end{array}$ & $\mathbf{5 5 \%}$ & & & & \\
\hline $\begin{array}{l}\text { Announcement of organizational chart of project } \\
\text { and its budget. }\end{array}$ & $\mathbf{2 5 \%}$ & $\mathbf{4 5 \%}$ & $\mathbf{4 5 \%}$ & & \\
\hline $\begin{array}{l}\text { Population participation in forming plans and } \\
\text { decision making. }\end{array}$ & $\mathbf{4 0 \%}$ & $\mathbf{6 0 \%}$ & $\mathbf{7 0 \%}$ & $\mathbf{7 5 \%}$ & \\
\hline Local councils coordination with local partners & & $\mathbf{8 0 \%}$ & $\mathbf{8 0 \%}$ & $\mathbf{8 5 \%}$ & \\
\hline $\begin{array}{l}\text { Publishing periodical reports about financed } \\
\text { authorities and their roles. }\end{array}$ & $\mathbf{4 0 \%}$ & $\mathbf{4 0 \%}$ & & \\
\hline $\begin{array}{l}\text { Public policy of publication and getting } \\
\text { information. }\end{array}$ & $\mathbf{3 5 \%}$ & $\mathbf{3 5 \%}$ & $\mathbf{3 5 \%}$ & $\mathbf{8 0 \%}$ & $\mathbf{8 0 \%}$ \\
\hline $\begin{array}{l}\text { A skeleton responsible for accountability } \\
\text { achievement. }\end{array}$ & $\mathbf{3 0 \%}$ & $\mathbf{3 0 \%}$ & $\mathbf{3 0 \%}$ & & \\
\hline $\begin{array}{l}\text { Consent reports include technical, financial and } \\
\text { administrative aspects. }\end{array}$ & $\mathbf{2 5 \%}$ & $\mathbf{2 5 \%}$ & $\mathbf{2 5 \%}$ & $\mathbf{1 0 \%}$ & $\mathbf{1 0 \%}$ \\
\hline $\begin{array}{l}\text { Regularity of participant categories meetings in } \\
\text { the project }\end{array}$ & $\mathbf{4 5 \%}$ & $\mathbf{4 5 \%}$ & $\mathbf{4 5 \%}$ & $\mathbf{7 5 \%}$ & $\mathbf{6 5 \%}$ \\
\hline $\begin{array}{l}\text { Mechanisms availability for achieving connection } \\
\text { between participant categories and beneficiaries. }\end{array}$ & $\mathbf{2 5 \%}$ & $\mathbf{3 0 \%}$ & $\mathbf{2 5 \%}$ & $\mathbf{7 0 \%}$ & $\mathbf{7 0 \%}$ \\
\hline $\begin{array}{l}\text { Mechanisms for achieving follow up and } \\
\text { monitoring in the project. }\end{array}$ & $\mathbf{1 5 \%}$ & $\mathbf{1 5 \%}$ & $\mathbf{1 5 \%}$ & & \\
\hline $\begin{array}{l}\text { Evaluating programs projects and plans } \\
\text { periodically. }\end{array}$ & $\mathbf{2 5 \%}$ & $\mathbf{2 5 \%}$ & & & \\
\hline
\end{tabular}

Views varied in the three projects, population in Ezaba Bekheet project agreed that there is no published statement of project and its objectives while the matter differed in two projects of Ezaba Al-Walda and Bolak as $60 \%$ of population answered by existing published statement while $40 \%$ of population didn't get this statement. $55 \%$ of benefiting population on the three projects level declared that they don't know project program and its population categories. Questionnaire showed that $70 \%$ of benefiting population doesn't have any information about stages of project and its definite time program.

$85 \%$ of participant sample in the three projects confirmed that there is no freedom in notifying information during work progress in the project, participatory planning project in Bolak El-Dakror recorded the greatest rate in transparency indicators in the three projects, as about $60 \%$ of total participant sample expressed about existing published statement and information about the project and some available information about work progress but they are not given completely to all population categories, questionnaire showed that the three participatory planning projects, high rates recorded between $45 \%$ - $65 \%$ concerning population participation in the view in projects requirements as workshops held with population contributed in 
identifying priorities and needs of projects before beginning work in the project and putting appropriate work plans through them, that helped on acquiring these projects validity and transparency in dealing with population.

The study displayed population objection on absence of published periodical reports that follow work progress and not holding workshops and periodical meetings with population during executing the project as the study displayed that rate of periodical reports about work progress in the project doesn't exceed 25\%, most of them are in Bolak El-Dakror.

Questionnaire was conducted for measuring transparency indicators for population towards role of non-governmental organizations in the project.

Questionnaire results were as what follow:

Questionnaire displayed that great non-governmental organizations have a fixed place in work location in the project by a moderate rate reaching $60 \%$ and that acquired validity for population about these organizations

Questionnaire displayed that most population by arte of $90 \%$ has no information about project budget in their areas and role of every participant nongovernmental association and its portion of participation while it displayed their information about participant organizations in the project by a rate that reaches $55 \%$ and names of these organizations while $60-70 \%$ of population have no information about sources of financing these organizations or their expenses on the project and that reduce transparency indicators while $75 \%$ of total sample population in the three projects confirmed that non-governmental organizations announce their activities in the project by a form that reaches all population, they make use of population in planning for its services and identifying its priorities in a form of periodical meetings and workshops with popular leaderships in the area. As for role of media means, population perceives that it has a weak and ineffective role by a rate that reaches $80 \%$ of population.

A questionnaire was conducted to measure transparency indicators for population towards governmental partners, questionnaire results were as what follow:

$85 \%$ of population confirmed that there are no clear financial and administrative systems for accounting those in charge of the project, project budget isn't announced and rates of participating in it is anonymous according to population. Questionnaire displayed that 75\% of participants in the sample perceives that there isn't enough awareness for government about accountability and possibility of achieving it ultimately, $45 \%$ of population reported that there is a private department for receiving complains in the project, but $95 \%$ of them reported that these complains are not dealt with honestly and neutrally, $70 \%$ of population reported that there is no announced skeleton of accountability during executing project after finishing it, questionnaire displayed that $85 \%$ of population confirmed that there are no published reports about project progress from financial sides and there is no supervisor for financial performance responsible for addressing and discussing population in project cost and its work progress, $90 \%$ of population reported that they have no role in evaluating government performance in the project.

Questionnaire was conducted for measuring transparency indicators for population towards non-governmental organizations work in the project, results were as what follow: 
$55 \%$ of population reported that there is no announced administrative financial system for making these organizations in the three projects, $75 \%$ of population confirmed that benefiting population has no right to account non-governmental organizations and has no supervision authority on them even though being partners in these projects, $85 \%$ of population reported that there are no systems to notify budget of participant organizations and sums spent in the project and way of distributing it, 75\% of population reported that there is a place for receiving complains even if there is no direct reaction on these complains, $85 \%$ reported that there is no supervisor of financial performance by government or population for non-governmental organizations, $85 \%$ of population confirmed that they have no role in evaluating non-governmental organizations performance in participatory planning projects.

By measuring indicators of transparency and accountability and extent of achieving them in the three projects through proposed measurement table and extent of every partner's achievement to his role in participatory planning projects in slum, results appeared as what follow:

Table No (8) results of measuring indicators of transparency and accountability of development partners in participatory planning projects in random areas and their roles in achieving indicators of transparency and accountability.

\begin{tabular}{|l|l|l|l|l|l|}
\hline Indicators of transparency and accountability & \multicolumn{3}{|c|}{ Partners of Participatory Planning } \\
\cline { 2 - 7 } & C.G & L.G & P.C & NGOs & S.O \\
\hline $\begin{array}{l}\text { Providing information about project objectives and } \\
\text { its program. }\end{array}$ & $\mathbf{2 5 \%}$ & & & & \\
\hline $\begin{array}{l}\text { Announcement of organizational chart of project } \\
\text { and its budget. }\end{array}$ & $\mathbf{2 5 \%}$ & $\mathbf{3 5 \%}$ & $\mathbf{3 5 \%}$ & & \\
\hline $\begin{array}{l}\text { Population participation in forming plans and } \\
\text { decision making. }\end{array}$ & $\mathbf{3 5 \%}$ & $\mathbf{5 0 \%}$ & $\mathbf{6 5 \%}$ & $\mathbf{6 5 \%}$ & \\
\hline Local councils coordination with local partners & & $\mathbf{6 0 \%}$ & $\mathbf{6 0 \%}$ & $\mathbf{6 5 \%}$ & \\
\hline $\begin{array}{l}\text { Publishing periodical reports about financed } \\
\text { authorities and their roles. }\end{array}$ & $\mathbf{2 5 \%}$ & $\mathbf{2 5 \%}$ & & \\
\hline $\begin{array}{l}\text { Public policy of publication and getting } \\
\text { information. }\end{array}$ & $\mathbf{3 5 \%}$ & $\mathbf{3 5 \%}$ & $\mathbf{3 5 \%}$ & $\mathbf{6 5 \%}$ & $\mathbf{6 5 \%}$ \\
\hline $\begin{array}{l}\text { A skeleton responsible for accountability } \\
\text { achievement. }\end{array}$ & $\mathbf{3 0 \%}$ & $\mathbf{3 0 \%}$ & $\mathbf{3 0 \%}$ & & \\
\hline $\begin{array}{l}\text { Consent reports include technical, financial and } \\
\text { administrative aspects. }\end{array}$ & $\mathbf{1 5 \%}$ & $\mathbf{1 5 \%}$ & $\mathbf{1 5 \%}$ & $\mathbf{1 5 \%}$ & $\mathbf{1 5 \%}$ \\
\hline $\begin{array}{l}\text { Regularity of participant categories meetings in the } \\
\text { project }\end{array}$ & $\mathbf{3 5 \%}$ & $\mathbf{4 5 \%}$ & $\mathbf{4 5 \%}$ & $\mathbf{6 5 \%}$ & $\mathbf{5 5 \%}$ \\
\hline $\begin{array}{l}\text { Mechanisms availability for achieving connection } \\
\text { between participant categories and beneficiaries. }\end{array}$ & $\mathbf{2 0 \%}$ & $\mathbf{2 5 \%}$ & $\mathbf{2 5 \%}$ & $\mathbf{5 5 \%}$ & $\mathbf{5 5 \%}$ \\
\hline $\begin{array}{l}\text { Mechanisms for achieving follow up and } \\
\text { monitoring in the project. }\end{array}$ & $\mathbf{1 5 \%}$ & $\mathbf{1 5 \%}$ & $\mathbf{1 5 \%}$ & & \\
\hline $\begin{array}{l}\text { Evaluating programs, projects and plans } \\
\text { periodically. }\end{array}$ & $\mathbf{1 5 \%}$ & $\mathbf{1 5 \%}$ & & & \\
\hline
\end{tabular}


As a result a questionnaire was conducted to measure the most important steps of enhancing transparency and accountability in participatory planning projects from benefiting populations' point of view, results were as what follow.

Table (9) results of questionnaire of steps reinforcing values of transparency and accountability from beneficiary population's point of view

\begin{tabular}{|l|l|l|l|l|l|l|}
\hline & \multicolumn{1}{|c|}{$\begin{array}{c}\text { Reinforcing steps of transparency and } \\
\text { accountability }\end{array}$} & $\mathbf{2 0 \%}$ & $\mathbf{4 0 \%}$ & $\mathbf{6 0 \%}$ & $\mathbf{8 0 \%}$ & $\mathbf{1 0 0 \%}$ \\
\hline 1 & $\begin{array}{l}\text { Announcing the project and its objectives by all } \\
\text { available means. }\end{array}$ & & & & & \\
\hline 2 & $\begin{array}{l}\text { Announcing partners of development, their role, } \\
\text { and liability. }\end{array}$ & & & & & \\
\hline 3 & $\begin{array}{l}\text { Declaring the organizational chart of the project } \\
\text { \& its budget. }\end{array}$ & & & & & \\
\hline 4 & $\begin{array}{l}\text { Declaring project's total budget and everybody's } \\
\text { share }\end{array}$ & & & & & \\
\hline 5 & Statement of project's progress. & & & & & \\
\hline 6 & $\begin{array}{l}\text { Existence of a headquarter in the project location } \\
\text { for development partners and their agents. }\end{array}$ & & & & & \\
\hline 7 & $\begin{array}{l}\text { Existence of announced administrative structure } \\
\text { to be responsible of accountability. }\end{array}$ & & & & & \\
\hline 8 & $\begin{array}{l}\text { Existence of auditor for financial performance. } \\
\text { Periodical reports of work's progress. }\end{array}$ & & & & & \\
\hline 10 & $\begin{array}{l}\text { Contribution of formal mass media in active role } \\
\text { in publishing and control. }\end{array}$ & & & & & \\
\hline 11 & $\begin{array}{l}\text { Population's right to evaluate performance of } \\
\text { development partners. }\end{array}$ & & & & & \\
\hline 12 & Free acquaintance of information about project. & & & & & \\
\hline 13 & $\begin{array}{l}\text { Availability of an internet site for viewing and } \\
\text { reply inquiries. }\end{array}$ & & & & & \\
\hline
\end{tabular}

\section{STEPS OF ENHANCING TRANSPARENCY AND ACCOUNTABILITY}

\section{4-1 Perception}

- The central government and decision-makers perceive the importance of transparency and accountability in all projects.

- Perceiving that forming and decision-making are fulfilled by needs and priorities of population and their participation in decision-making.

- Perceiving the significance of establishing general policy for publication and disclosure of information concerning population, due to frameworks defining bases of obtaining this information.

- The central government and civil organizations perceive the population's right of accountability all over all stages of project and till its accomplishment. 


\section{4-2-Preparation}

- Availability of an integrated program for project's objectives and strategies.

- Availability of integrated database of project, its progress, budget, and beneficiaries.

- Availability of an organizational chart of development partners and those in charge of the project to highlight each one's role and liability.

- Determining number of participant authorities, since increased numbers decrease effectiveness of their roles.

- Availability of all information and data for all partners equally, including beneficiary population.

- Availability of specific system for determining nature and form of accountability through a lawful framework that controls relations among those in charge of project.

- Availability of a strong role of the mass media to achieve transparency and accountability being a partner in development project.

\section{4-3- Implementation}

- Availability of periodical reports includes technical, financial, and administrative aspects.

- Regularity of meetings of development participants in the project.

- Availability of a mechanism for monitoring and following up during project's execution.

- Availability of specific mechanism for publication across internet, printed out booklets, visual means, workshops and meetings.

- Availability of mass communication management that would be responsible for publication of everything concerning the project such as implementation stages, timetables, expenses, roles, charges of partners and their commit towards implementation.

- Availability of mass communication statement of the following procedures of accountability set by those in charge of the project through the following legal frameworks.

- Determining the scope of broadcasting of information and population category precisely.

\section{4-4 Evaluation}

- Evaluate programs, projects and plans periodically

- Enable the beneficiary population to assess the impact of participatory planning projects through methodology steps.

- Evaluate the roles of partners and their commitment of responsibilities, to activate their roles in the future. 


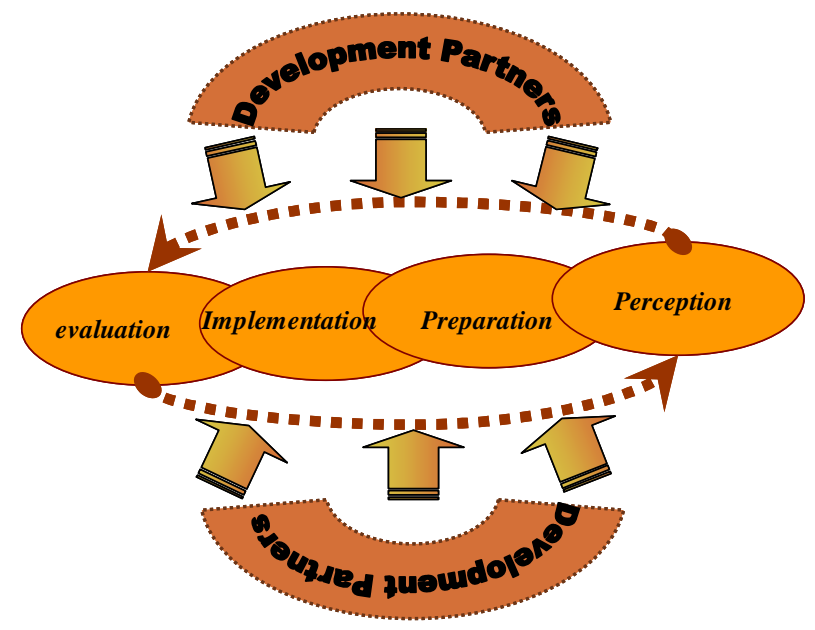

Shape (6) clarifies steps of enhancing values of transparency and accountability in participatory planning projects in random areas "Source. Researcher Preparing"

\section{CONCLUSION}

Accountability and transparency are two sides of one coin contribute achieving participatory planning and activating its role. The central government being represented in ministries, quarters, and local councils have achieved limited success producing transparency in participatory planning projects in slum despite the existence of some defects resulted in the non-commitment of the government and the other concerned authorities of following clear bases and steps in all projects, except for some individual efforts by those in charge. Regarding accountability, no indicators are shown to be fulfilled; because of the government's lack of perception of principle of accountability, specifically, the beneficiary population' right to call to account those in charge of the participatory planning project, evaluating their performance either.

Non-governmental organizations have achieved greater success than central government regarding transparency of performance through which they have acquired credibility of beneficiary population. Nevertheless, it is a limited credibility sometimes because of absence of announcement of their objectives, financing resources, roles, and responsibilities pertaining projects relying on these organizations and their accountability structure but after they promote their performance that may qualify them to a bigger role in future projects.

The government and civil organizations should devote greater part of their effort and interest to publicity of their participatory planning projects in the slum; exploring as well their role through publicity campaigns to be leaded by formal media, reaching finally to all beneficiary categories, making the project a national project and part of priorities and concern of everybody of community.

Finally, all development partners should follow steps that enhance values of transparency and accountability, setting defined plans to fulfill these values in participatory planning projects in slum, activating as well these projects' performance and role to acquire them credibility of population. 


\section{REFERENCE}

${ }^{1}$ http://208.77.188.200/lists/principles comments/pdfGTBeUoIu4m.pdf .

${ }^{2}$ M. Bordignon, E. Minell: (2001)," Rules transparency and political accountability", Journal of Public Economics 80.

3 W. Daft: (2010), "social responsibility and transparency", McGraw- Hill book co, N.Y.

${ }^{4}$ C. Auclair, A. Jackohango:(2009), "Good Urban Governance: Towards an Effective", Private Sector Engagement", Private Sector Unit - UN-HABITAT June 2009.

${ }^{5}$ R . Stephen: (2010), "Transparency Concept and Application", Prentice Hall, Inc, New York.

${ }^{6}$ B. Proker: (2010), "Globalization and Transparency strategies", West publishing Co, New York.

${ }^{7}$ http://www.sasanet.org/documents/Case\%20Studies/Participatory\%20Planning\%20Ke rala\%20Case\%20Study.pdf

${ }^{8}$ P. Maurice, Mc Tigue, Q.S.O. :( 2007), “Transparency and Accountability in Louisiana" The Mercatus Center at George Mason University.

${ }^{9}$ J. Peter: (2009), "Transparency and Accountability in international financial institution", Geneva, Switzer land.

${ }^{10}$ P. Carolyn: (2010), "The Mechanisms of transparency", john wiley \& Sons, Inc, New York.

11 B. etal: (2006), "Fundamentals of Transparency", 2nd Edition, Irwin INC, New York.

${ }^{12}$ Secretary (Planning \& Economic Affairs) \& Secretary (Local Self GovernmentRural) Prepared for the Workshop-cum-Training Programmer On 'Application of Social Accountability Mechanisms in Community Driven Development and Decentralization Programmers' in South Asia at Hyderabad 16th to 19th May 2005 Organized by the World Bank and Centre for Good Governance

${ }^{13}$ F. Davidson, ,M. Peltenburg, (1993) "Government and NGOs / CBOs Working Together for Better Cities", HIS Working paper series, No.6 , Institute for Housing and Urban Development Studies "HIS", Rotterdam.

${ }^{14}$ M. Clarke, J. Stewart :( 1992), "The Challenge for The Government of The Cities", Local Government Policymaking 18.

15 The Global transparency initiative: (2010), "transparency at the IMF, A guide for civil society on getting access to information from the IMF", Britton woods project, London, 2010.

16 J. Clark, :( 1991)" Democratizing Development: the Role of Voluntary Organizations", Earth scan Publications, London.

${ }^{17}$ E. Armstrong: (2008), "Transparency in Non-Governmental organization", john Wiley\& Sons, New York.

${ }^{18}$ G. Hultman: (2007), "Creating financial transparency in NGOs, examining best practices of partners", Journal of public health management\& practice, Yale university. 


\title{
Questionnaire appendix (1)
}

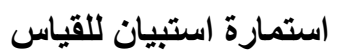

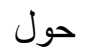 \\ قياس مؤشرات الثفافية و المساءلة في مشرو عات التخطيط التشاركي بالعشو ائيات \\ وطرق تعزيز الثفافية والمساءلة الثطيط
}

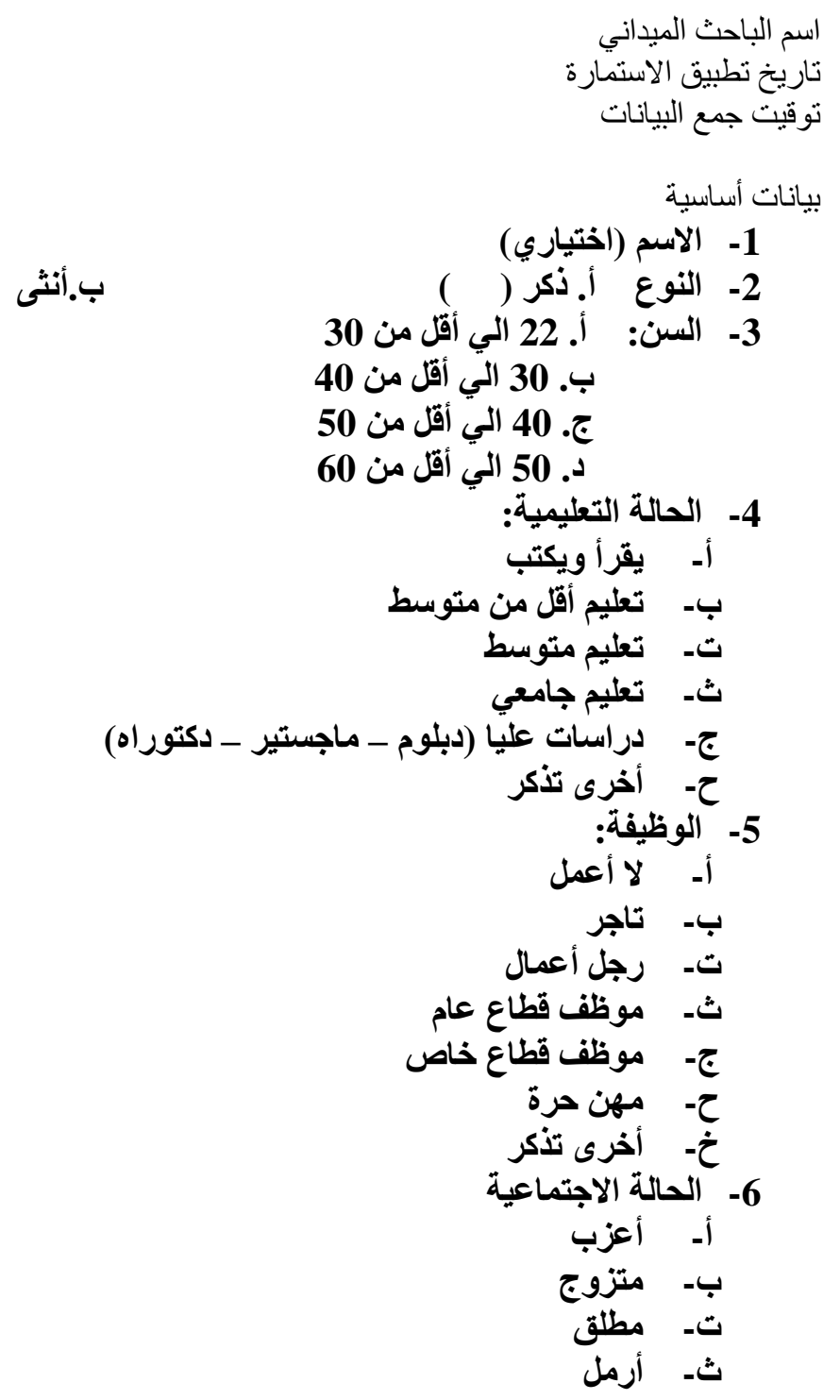


بيانات خاصة بادراك السكان المنتفعين للشفافية في التعامل مع الثركاء الحكوميين العاملين بالمشروع

\begin{tabular}{|c|c|c|c|c|}
\hline 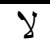 & الي حد مـا & نعم & العبارة & 7 \\
\hline & & & يوجد بيان منشور عن المشروع و أهدافه & -1 \\
\hline & & & يوجد بيان محدد ببرنامج المشروع و الفئات المستهدفة & -2 \\
\hline & & & يوجد بيان محدد بمر احل سير العمل بالمشروع & -3 \\
\hline & & & يوجد حرية اطلاع على مفردات سير العمل بالمشروع & -4 \\
\hline & & & يوجد سهولة في البيانات و المعلومات المتعلقة بالمشروع & -5 \\
\hline & & & أشـارك بالر أي في منطلبات المشروع و احتياجات المكان & -6 \\
\hline & & & 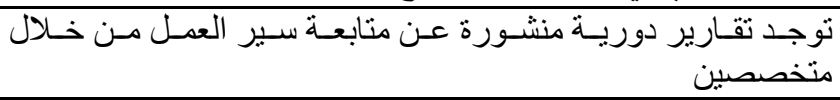 & -7 \\
\hline & & & ومتابعته اجتماعـات مسـتمرة مـع القيادات الثـعبية بخصـوص المشـروع & -8 \\
\hline
\end{tabular}

بيانات خاصة بادر اك السكان المنتفعين للثفافية في التعامل مع الثركاء غير الحكوميين العاملين بالمشروع

\begin{tabular}{|c|c|c|c|c|}
\hline $\mathrm{y}$ & 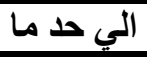 & نعم & العبارة & 1 \\
\hline & & & يوجد مقر ثابت لتواجد مندوب للشركاء غير الحكوميين & -1 \\
\hline & & & يوجد بيان بميز انية المشروع ونصيب كل مشارك من المشروع & -2 \\
\hline & & & 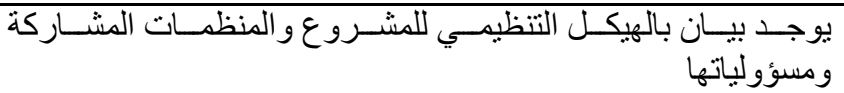 & -3 \\
\hline & & & المنظمات المشاركة تعلن عن أنشطنها بصورة تصل للجميع & -4 \\
\hline & & & مصادر تمويل المنظمات الأهلية واضحة & -5 \\
\hline & & & المنظمات المشاركة نفقاتها غبر واضحة & -6 \\
\hline & & & التخطيط لخدماتهـار كة تحرص على مشـاركة السكان المستفيدين في & -7 \\
\hline & & & توجد متابعة ومر اقبة جيدة من وسائل الاعلام للمنظمات المشاركة & -8 \\
\hline
\end{tabular}

بيانات خاصة بادراك السكان المنتفعين للمساءلة في التعامل مع الثركاء الحكوميين العاملين بالمشروع

\begin{tabular}{|c|c|c|c|c|}
\hline $\mathrm{y}$ & 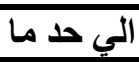 & نعم & 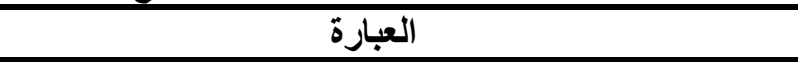 & 2 \\
\hline & & & يو جد أنظمة مالية و ادارية محددة وو اضحة & -1 \\
\hline & & & يو جد وعى لاى الحكومة بحق السكان المستفيدين في المساءلة & -2 \\
\hline & & & يو جد قسم خاص بالهيكل الاداري لتلقى شكاوى السكان المستفيدين & -3 \\
\hline & & & يتم التعامل مع جميع الثكاوى بنز اهة وحيادية & -4 \\
\hline & & & يو جد تسلسل و اضح لهيكلة المساءلة & -5 \\
\hline & & & يو جد مر اقب للاذذاء المالي بالمشروع & -6 \\
\hline & & & توجد تقارير منشورة عن سير المشروع من النواحي المالية & -7 \\
\hline & & & يشارك السكان المستفيدين في تقييم أداء المشروع & -8 \\
\hline
\end{tabular}


بيانات خاصة بادراك السكان المنتفعين للمساءلة في التعامل مع الشركاء غير الحكوميين العاملين بالمشروع

\begin{tabular}{|c|c|c|c|c|}
\hline$y$ & الي حد مـا & ن انم & 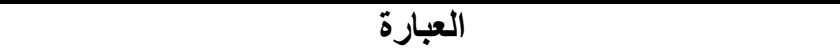 & Y \\
\hline & & & يوجد أنظمة مالية وادارية محددة وو اضحة للمنظمات الأهلية & -1 \\
\hline & & & تتيح المنظمات الأهلية لكل الشركاء حق المساءلة & -2 \\
\hline & & & بوجد قسم خاص بالهيكل الاداري لتلقى شكاوى السكان المستفيدين & -3 \\
\hline & & & يتم التعامل مع جميع الشكاوى بنز اهة وحيادية & -4 \\
\hline & & & يوجد بالمنظمات الأهلية أنظمة تسمح بالاطلاع على ميز انيتها & -5 \\
\hline & & & بوجد مر اقب للأداء المالي بالمشروع & -6 \\
\hline & & & الداخلية وتقييم الأداء تخطيط لبنـاء قدر ات العـاملين بها في مجـال الرقابـة & -7 \\
\hline & & & يشارك السكان المستفيدين في تقييم بر امج و أداء المنظمات الأهلية & -8 \\
\hline
\end{tabular}

\section{نحو تعزيز قيم المساعلة والثفافية لتفعيل منظومة التخطيط التشاركي}

إن إدارة العمران في مصر تواجه العديد من التحديات في ظل العولمة واتفاقيات التجارة ومفاهيم الاستدامة ولذلك كان لابد لإدارة العمران من أن تجاري منطلبات العصر وتحدياته وتلبي احتياجاته. هذا وقد ظهرت العديد من المفاهيم التي ارتبطت بالتقدم في إدارة العمران منها الإدارة الحضرية والثراكة وإدارة

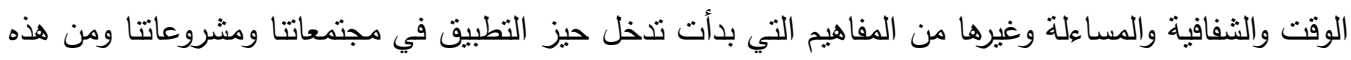

المفاهيم مفهوم التخطيط التشاركي الذي أصبح احد المفاهيم المستخدمة في العديد من مشروعانتا القومية. الثفافية والمساءلة مقومان أساسيان من مقومات الادارة الحضربة التي تشكل شرطاً مسبقاً من شروط تحقيق التتمية المستدامة وهما مفهومان منرابطان يعزز كل منهما الآخر ففي غياب الثفافية لا يمكن وجود المساءلة وما لم يكون هناك مساءلة فلن يكن للشفافية أي قيمة. تهذف الورقة البحثية الي التوصل الي خطوات منهجية لتعزيز قيم المساءلة والثفافية بمشروعات تطوير العشوائيات لتفعيل منظومة التخطيط النتشاركي. تعتمد خطة البحث على أربعة محاور أساسية المحور الأول ":التعرف على مفهومي الثفافية والمساءلة ومنطلبات ومؤشرات تطبيقهما. المحور الثاني التعرف على مفهوم التخطيط التشاركي ومنطلبات نطبيقه للتوصل الي دور المساءلة والثفافية في تفعيل التخطبط التشاركي. المحور الثالث: اجراء استبيان لقياس مؤشرات الثفافية والمساعلة في عدد من مشروعات التخطبط التشاركي بالعشوائيات .

المحور الرابع : التوصل الي خطوات لتعزبز قيم المساءلة والثفافية. ويتم التعامل في الورقة البحثية مع مفهومي الثفافية والمساعلة على أساس أنهما من أهم مقومات تحقيق التخطيط التشاركي وأنهما من أدوات تفعيل الإدارة الحضرية الجيدة وتمثلان نجاح ومصداقية لمشروعات التخطيط 
وأخيراً على جميع شركاء النتمية اتباع الخطوات التي تعزز من قيم الثفافية والمساءلة ووضع خطط محددة

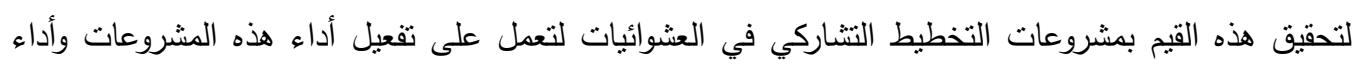

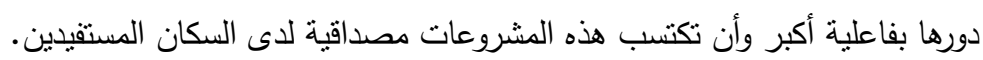

